\title{
Golija-Studenica Biosphere Reserve (Serbia) as a Driver of Change
}

\author{
Marijana Pantić, Nataša Čolić \& Saša Milijić \\ Keywords: biosphere reserve, Golija-Studenica, Serbia
}

\section{Abstract}

In the 50 years since the UNESCO Man and the Biosphere Programme (MAB) was launched, 727 sites in 131 countries have gained the status of biosphere reserve (BR). Golija-Studenica BR belongs to the group of BRs that have been active for the past 20 years. This BR is one of the most prominent protected areas and the first of its kind in Serbia. A balance between biodiversity conservation, as the primary goal of protection, and the promotion of sustainable profitable activities involving diverse actors has yet to be achieved. This research aims to provide a contextual understanding of changes in Golija-Studenica BR and draw lessons for future BR development. It relies on the experiential and practical knowledge of diverse stakeholders, including management bodies, the NGO sector and the local population itself. The methodology is based on a qualitative approach, using semi-structured interviews with open-ended questions. Research results show that the BR model is a subtle, time-reliant driver of change, with some unintentional side-effects. It brings about changes in how protected areas are managed, affects the economic behaviour of the local population, raises awareness about environmental issues, and has an impact on demographic trends and social change.
Profile

Protected area

Golija-Studenica

Biosphere Reserve

Mountain range

Dinaric Alps

Country

Serbia

\section{Introduction}

\section{Contextual background}

Golija-Studenica Biosphere Reserve (GSBR) was set up in 2001, thirty years after UNESCO commenced the MAB Programme. Located in south-western Serbia, a mountainous area on the eastern edge of the Dinaric Alps, the BR encompasses 53804 ha of Golija Mountain. It has never been densely populated. Today, there are about 6000 inhabitants, in 42 settlements, who are predominantly engaged in animal husbandry, and gathering herbs and mushrooms (Tomić \& Stojsavljević 2013). Traditional settlements, in the form of hamlets and scattered households, are found up to an elevation of $1300 \mathrm{~m}$ (the mountain's summit is at $1833 \mathrm{~m}$ ). A traditional lifestyle based on agriculture evolved, creating a landscape of pastures, meadows and forests (Figure 1). The natural values of Golija are still being revealed through the discovery of new habitats, flora and fauna (Vukojičić et al. 2019; Sabovljević et al. 2020). At the north-eastern edge of the BR is Studenica Monastery, a UNESCO cultural World Heritage site, built in the $12^{\text {th }}$ century (UNESCO 2017). Parallel to its BR status, Golija received national protected status as a nature park (NP). The NP (which includes the BR) extends south from the BR to encompass a total of 75183 ha (Institute for Nature Conservation of Serbia 2020) (see map, Figure 2).

In recent decades, tourism on Golija has developed alongside traditional economic activities; it is recognized as a factor in rural revitalization and the preservation of traditional architecture and customs (Sagić et al. 2019). Golija's scenic landscapes, clean environment and tranquility distinguish it from other mountain areas in the vicinity (e.g. Kopaonik and Zlatibor) (Tomić \& Stojsavljević 2013; Lakićević \& Sagić 2019). Sustainable development of the area is enhanced by rural tourism businesses, which are usually small-scale, together with cultural tourism as another pillar of development in GSBR (Terzić et al. 2014; Lakićević \& Sagić 2019). Although GSBR is recognized as a site of national importance for the Republic of Serbia, the area is exposed to diverse internal and external influences regarding protection, on the one hand, and economic development, on the other. This issue has been recognized in international research papers that deal with the subject of BRs (e.g. Bridgewater 2002; Krušova et al. 2008; Price et al. 2010; Ishwaran 2012; Castillo-Eguskitza et al. 2017; Kratzer 2018).

Based on the fifty-year implementation of the MAB Programme, Ishwaran (2012) sees BRs as having great potential as sources for learning about sustainable development at all territorial levels. According to Tomić \& Stojsavljević (2013) and Terzić et al. (2014), Golija undoubtedly has this capacity, too. So far, there has been a gap between the concept and the reality (Schultz et al. 2018), which "calls for more indepth research on the BR-specific interpretations of problems" (Kratzer 2018, p. 329). The evaluation of protected areas, including BRs, is a neglected issue, despite its relevance in the domain of sustainable management (Yihe et al. 2003). It was therefore one of the objectives of the Seville Strategy (1995) to make the evaluation of all MAB areas and the submission of reports obligatory (Cuong et al. 2017a). The evaluation process is 


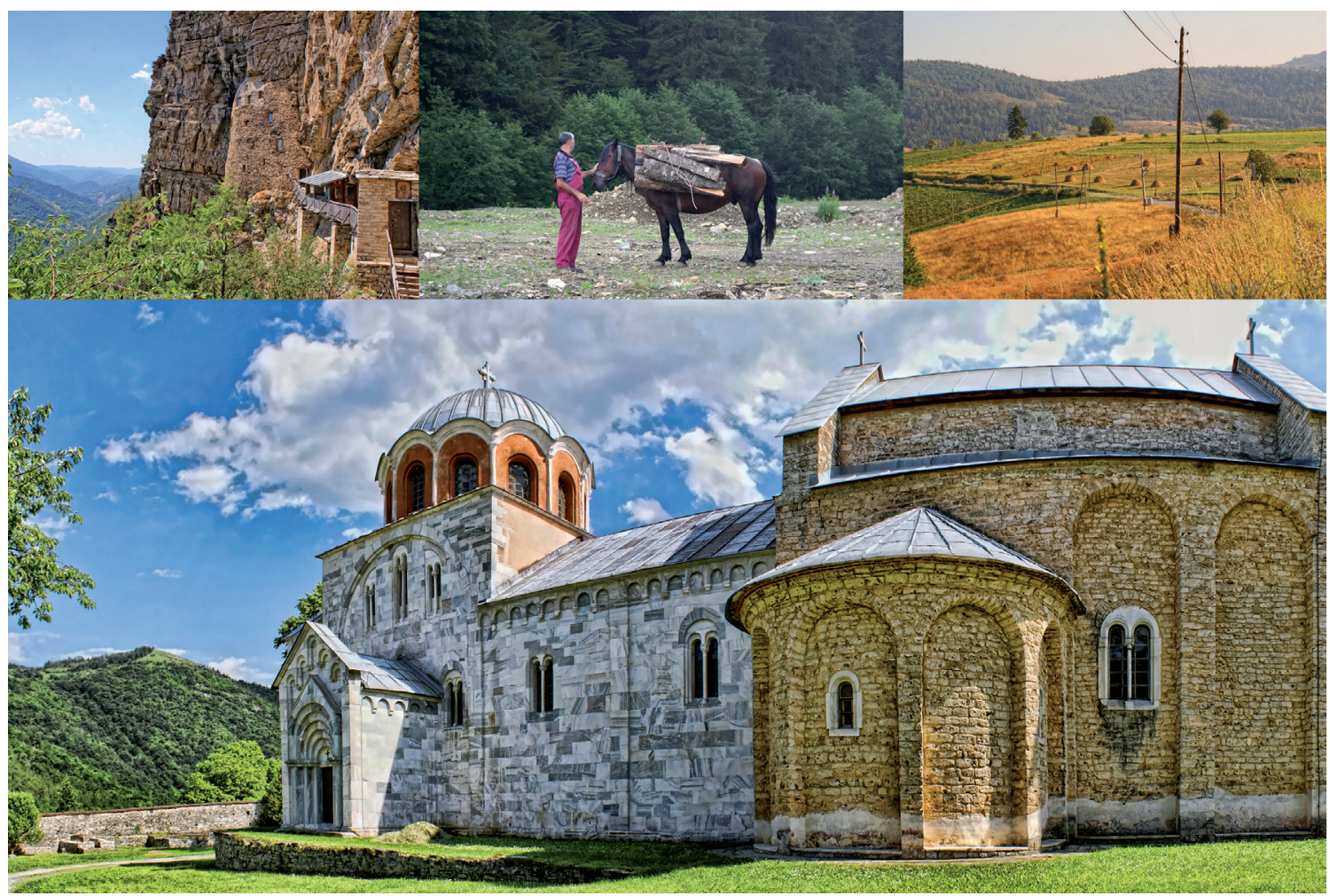

Figure 1 - Top: St. Sava's hermitage; hauling wood in Golijska Reka; Golija landscape in Brovik village; Bottom: Studenica Monastery. (C) the authors

simultaneously a learning practice that contributes to adaptive management (Hockings et al. 2006).

\section{Theoretical background}

The concept of environmental protection is based on the notion that development in areas of valuable natural resources should be controlled (Yihe et al. 2003). However, restrictive protection is not always necessary or justified. Thus, the UNESCO MAB Programme strives to create a balance between natural and manmade systems (UNESCO 1995). This is different from traditional protection concepts, since it ascribes an equal value to natural landscapes and to sustainable, manmade ones (Bridgewater 2002; Trkulja 2005). The BR concept addresses the simultaneous conservation of biological and cultural diversity; the inter-relationships between ecological, economic and social aspects; research, monitoring, education and training (Price et al. 2010; UNESCO 2016; Pool-Stanvliet et al. 2018). To become a BR, an area needs to demonstrate diverse and representative forms of sustainable development, and to be of an appropriate size within the regional context (Ibid). In addition, BRs should meet organizational requirements. The protected area must have a legal constitution; demonstrate active information exchange and cooperation between stakeholders at all levels; and have an established management body with capacities to create and implement plans (Price et al. 2010; Pool-Stanvliet et al. 2018).

Designation as a MAB BR represents an award, but it requires a management capable of balancing conser- vation and development (Schultz \& Lundholm 2010). Establishing quality management of a BR is relevant not only at the local and regional levels, but also regarding cooperation with other BRs - nationally and internationally. Thus, a BR can be a successful tool for coordinating regional development, fundraising and extending sustainability outside its territorial boundaries (Pool-Stanvliet \& Giliomee 2013; Kratzer 2018). UNESCO has developed an international framework for the evaluation of BR effectiveness, thus controlling the implementation of the MAB programme's principles and standards (Berkes 2007). The framework requires the fulfilment of preconditions for reserve designation and obligatory periodic reports, as defined in the Seville Strategy (1995) (Reed \& Egunyu 2013; Cuong et al. 2017a). Among these preconditions are establishing a management body and drawing up a management plan to demonstrate how the BR hostcountry is able to carry out tasks independently, and to contribute to MAB objectives (Schliep \& Stoll-Kleemann 2010). According to Price et al. (2010) and Reed \& Egunyu (2013), the periodic reports represent not only evaluation tools, but also an opportunity to reflect and share good practice with other BRs. The relevance of the evaluation framework is reflected in the greater success of post-Seville reserves in achieving higher levels of sustainability and a balance between development and protection (Cuong et al. 2017a).

According to Schultz et al. (2018), BRs still suffer from a concept-reality gap, mainly due to a poor understanding of what the model represents and how 


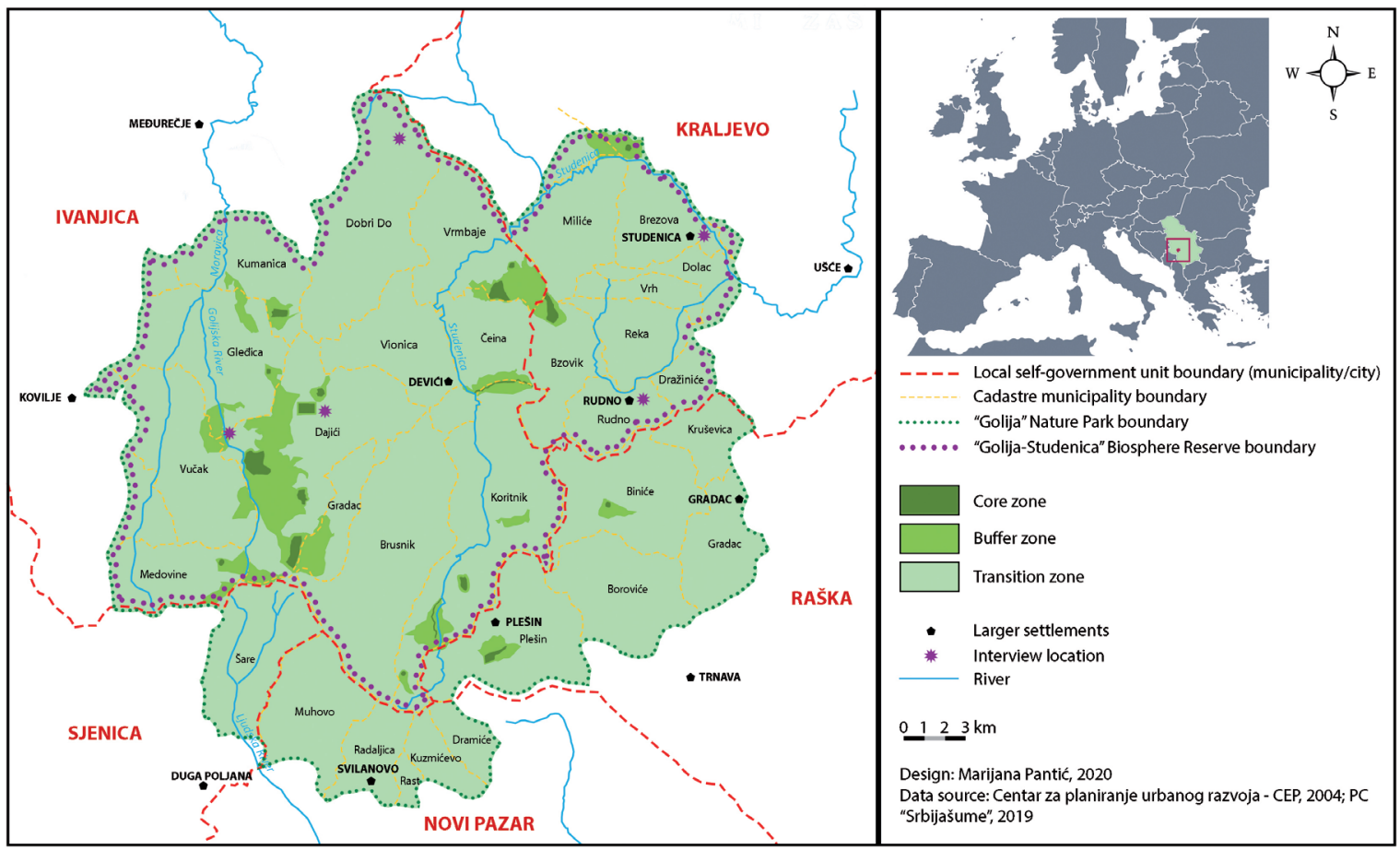

Figure 2 - Golija-Studenica Biosphere Reserve and Golija Nature Park.

sustainable development should be managed. Common problems include uncoordinated plans, central government interference, excessive exploitation of resources, strict protection of natural resources, and limited participation by local stakeholders (Cuong et al. 2017b). BR host countries face challenges from institutional and structural flaws (e.g. legislation, insufficient capacity, and lack of technical skills, which hinder implementation at the local level (Kušová et al. 2008; Schliep \& Stoll-Kleemann 2010; Cuong et al. 2017b; Pool-Stanvliet et al. 2018). On the other hand, conflicts between the newly established protection and the traditional use of resources (e.g. quarries) at the local level "can increase vulnerability and compromise individual and collective agency for adaptation" (Ruiz-Mallén et al. 2015, p. 97). Therefore, the MAB framework and supporting research suggest the importance of participation by stakeholders from different sectors and levels in order to enhance implementation of the concept (Trakolis 2001; O’Riordan \& Stoll-Kleemann 2002; Price et al. 2010).

\section{Aims}

The main aim of this paper is to identify and examine the extent to which UNESCO BR status relates to changes in the biodiversity, socio-economic development and management of the protected area. Following one of the main principles of the BRs, namely participation, this research involved stakeholders from different fields.

The remainder of this paper is structured as follows: Methodology, Findings, Discussion and Conclusions. The Findings distinguish Changes in GSBR from the Challenges of change.

\section{Methodology}

In order to follow the changes that have occurred since GSBR was established, this empirical study employs qualitative research (Bryman 2016). Experiential and practical knowledge are crucial elements of the co-production of sustainable development practices in BRs. This is why a participatory approach is frequently used in qualitative BR research (Chapin et al. 2009). Current BR research utilizes surveys (e.g. Yihe et al. 2003; Schultz et al. 2011; Hernes \& Metzger 2017) and interviews (e.g. Schliep \& Stoll-Kleemann 2010; Ruiz-Mallén et al. 2015) to identify and examine the causes of change (Yihe et al. 2003). This paper aims to decode the rich practical experience of experts, stakeholders, policymakers and local users in order to provide a contextual understanding of changes in GSBR.

The data was collected through interviews conducted with the main stakeholders identified in GSBR development documents, and later via snowball sampling. The participants included representatives of BR management bodies, local self-government and national government (the Ministry in charge of spatial planning), research institutions, regional and EU development agencies, Local Action Groups (LAGs), mountaineering clubs, and local community members. In total, there were 23 interviewees, 15 of whom came from 11 institutions (public and private), while the remaining 8 were randomly sampled interviewees approached in the field (i.e. in the BR itself) (Figure 2).

The questionnaire used in the interviews contained open-ended questions, which were amended slightly according to the experience and affiliation of the interviewees. They covered topics such as biodiversity, 
socio-cultural-economic development, and BR management. The interviews, which were conducted via telephone, Skype or in person, were audio-recorded, while conversations with participants in the BR were recorded in writing. Except for the interviews with families and those with the BRs' managers based in Belgrade (in the public enterprise responsible for state forests), all conversations were one-on-one. The anonymity of the participants was ensured; their affiliations are not included in the Findings section. Only those participants who gave their permission are listed in the Acknowledgments section.

The research applied an interpretive approach to data analysis and the thematic coding of narratives. The aims were to showcase participants' views about changes and challenges in GSBR, and to identify the issues and potentials involved in consolidating bottom-up and top-down approaches to sustainable development practices in this particular case. Additionally, the research identified professionals and local users as significant reservoirs of knowledge and expertise (Čolić \& Dželebdžić 2018). The discussion section relates findings to the current literature.

\section{Findings}

The first part of this chapter (Changes in GSBR) uses narratives to present some of the main changes in GSBR in the domains of biodiversity, socio-cultural and economic development, and BR management. Along with the changes, challenges were identified in the implementation of the BR model, which are presented in the chapter Challenges of change.

\section{Changes in GSBR}

The subject of promoting the cultural heritage of Golija comes to the fore when discussing the positive effects of BR status. The combination of Studenica Monastery UNESCO World Heritage Site and the GSBR has increased the attractiveness of the area and highlighted the need for conservation of the cultural heritage.

"Studenica Monastery was inscribed on the UNESCO list in 1986. Although it is a pearl of our medieval architecture located in a fantastic forest, the monastery was not [sufficiently] exploited until a decision was made to declare it a biosphere reserve [...]. Declaring a biosphere reserve contributed to recognition of the monastery and its promotion as having exceptional potential for Serbia, in terms of both cultural heritage and tourism." (Interview no. 13)

This interviewee explains that BR status provided a certain level of financial security for Studenica Monastery, but also for other cultural heritage sites within GSBR and its vicinity (Gradac, Pridvorica, Đurđevi Stupovi and Sopoćani monasteries, Stari Ras medieval fortress, Church of the Holy Apostles Peter and Paul, St. Sava's hermitage). Additionally, interviewees noted that BR status had a positive effect on the development of tourism, which has contributed to the local economic transformation of Golija, encouraging people to return to the area to live, and implicitly slowing down outmigration:

"Tourists come here because of the clean air, pristine nature and cultural heritage [...]. I would estimate that the pioneers of tourism in Golija are mostly permanent residents, but also returnees who have lived in the city [...]. Many current inhabitants are former visitors who wanted to come and live here permanently. I am thrilled that people are coming back! We have 3-4 recent examples where younger couples with children bought large properties to live here and further contribute to tourism." (Interview no. 4)

Besides promoting cultural heritage, BR status has helped draw international attention to Golija as a tourism destination, thus promoting the area as a whole at national and international levels:

"The largest proportion of our tourists come from countries in the Far East, who greatly appreciate the connection between natural and cultural assets which Golija offers. That's what they're all fascinated by! When I ask them how they found out about Golija, they often mention the UNESCO website." (Interview no. 13)

Tourism is mentioned by most interviewees as newly emerging and one of the most cost-effective activities for the local population. The UNESCO BR concept emphasizes the practice of "traditional lifestyle and indigenous uses of biodiversity" (UNESCO 2020, Article II.B.4.). This approach enhances the preservation of traditional materials and activities, and awareness of these by tourists (local food, recipes, textiles and clothing, use of traditional materials in construction, etc.).

"The family I visited served us juice, jam and brandy as their home-made products [...]. The house and signs for tourists are made of the local wood [...]. Younger hosts take care of the guests, while the elderly engage in agricultural activities. They grow raspberries, chokeberries [...]. They have two cows, poultry..." (Researcher's field observation)

Some interviewees mentioned that BR status has had some (but minor) effect on the improvement of sustainable public services. Interviewees noted that the development of tourism has motivated some people to remain in Golija, or to return or move there, which justifies keeping some public services:

"Well, maybe, thanks to tourism, the population size has remained about the same, and public services along with them $[\ldots]$. The number of school children has increased in the village of Devici [there are about 100 children] in parallel with the number of inhabitants of the village and the development of rural tourism. At the moment, existing school capacities are sufficient. Some post offices were supposed to shut down, but we still have them in several villages [Gradac, Rudno, Devici, Studenica and Bratljevo]. We have several outpatient clinics as well, but we do not have a permanent doctor. Doctors travel to villages several days a week - on Monday, Thursday, Friday, something like that [...]. It is a problem when you have to chase a doctor, especially in the snake or bee season." (Interview no. 9) 
Hand in hand with the development of tourist activities and the adoption of spatial plans in GSBR, construction land has increased in value. This has led to illegal construction, particularly at the outer edge of the BR:

"After the proclamation of the biosphere reserve and adoption of a spatial plan for Golija in 2001, illegal construction started almost immediately. This development occurred without a development plan for the Odvracenica area in particular [...]. Inspectors came out and handed demolition orders to the developers. However, the Legalization Act gave all those buildings legal status [...]. This year, the trend of illegal construction is slightly reduced. It happens that two or three out of 20 buildings are built illegally every year." (Interview no. 3)

"We have an illegally erected settlement of weekend cottages built partly in the national park core zone-Odvracenica. This was why part of the core zone was converted into a buffer zone. Simply, biosphere protection status raises the value of the land, bringing an increase in the number of weekend cottages [...]. That land is privately owned and everyone wants to do whatever they want on their property. Neighbours copy this bad practice from each other." (Interview no. 17)

The issue of illegal construction might be resolved in the future because BR status authorizes the Management Office (MO) to monitor development activities, even on land that is not in their ownership. However, the $\mathrm{MO}$ is not in charge of issuing building permits, nor does it have the authority to suspend construction. These limitations on the MO's powers are another formal constraint for sustainable development of the area.

"Our obligation is to monitor construction activities according to the terms issued by the Institute [for Nature Conservation of Serbia]. However, 3-4 years ago, it happened that local authorities issued permits without the permission of the Institute, so we had a meeting with state inspectors and urbanism departments from all the local authorities. We instructed them not to bypass the Institute. So, it's all right now." (Interview no. 9)

Some illegal development activities are due to the local population's lack of awareness about procedures regarding construction in a $\mathrm{BR}$. The $\mathrm{MO}$ organized training sessions for local inhabitants to demonstrate to them the benefits of living in a protected area, and to improve their capacity to engage in sustainable activities such as the collection and sale of medicinal herbs, or branding local products. One interviewee spoke about the challenge of bringing about a change of heart in the GSBR's local community regarding the exploitation of natural resources such as wood and stone:

"It is very important for the local community to become acquainted with all the advantages of protected areas and the benefits they may bring to the private sector. Protection is not a punishment for the local community. Unfortunately, most residents of areas such as Golija understand protection as being extremely restrictive for their lives and business. They should be instructed about the benefits of living and working in a protected area and become its guardians and protectors. The Action Plan for Golija was conceived with this vision." (Interview no. 16)
The sustainable exploitation of BRs requires participatory decision-making (Ibid), which is still only developing gradually in Serbia. The interviewees' experience suggests that preparation of the Action Plan for Golija NP helped to implement a participatory approach and better cooperation in the management of the BR. Some interviewees explained that establishing the BR has gradually created an awareness of the advantages of cooperation:

"One of the main aims of the Action Plan for Golija National Park was to improve public participation in decisionmaking processes and establish a sustainable management model to serve the socio-economic and environmental development of the biosphere reserve [...]. We contacted representatives of public enterprises, local inhabitants and grass-roots organizations, local and national administrations, even retired architects from the local area. Around 120 school children from Golija participated in a drawing competition to suggest the future look of Golija [...]. Public participation improved the integrity of the process and collaboration and mutual trust between people, as well as between institutions. (Interview no. 3)

The process of creating the Golija NP Action Plan provided an arena for improved communication at different levels - between administrative bodies in charge of the BR, municipal representatives, national body representatives and local citizens. This process increased the participation of the local community in envisioning the future of the BR, which led to the formation of LAGs. Institutions in charge of nature conservation and the MO continually communicate with the local inhabitants. The fact that the MO leader is a member of the local community facilitates direct communication with its members.

"As a Local Action Group, we cooperate with local (municipal) councils and associations, but also ministries. We have been collaborating for more than 20 years [...]. And in terms of implementation, we cooperate with everyone, depending on the topic and the need for the project and our actions [...]. When someone who worked with you 20 years ago still wants to work with you - that says something about both the organization and the people who work for it." (Interview no. 6)

Establishing the BR, as well as the process of drawing up the Golija Action Plan, brought about changes in governance practices within the BR and an expansion of activities of the $\mathrm{MO}$, which is part of a public enterprise in charge of state-owned forests. The MO's actions expanded to research and monitoring activities and financial support to complementary institutions (e.g. the Institute for Nature Conservation of Serbia, and the Institute for the Protection of Cultural Monuments Kraljevo).

"The benefit of protecting the area is that you have the finances and you can engage people [other institutions] in research. We plan to do a lot [of research] in the coming period - in the field of geology, culture and biodiversity. We are engaged in monitoring protected species [...]. We cooperate with the Faculty of Biology, which discovered that there are certain strictly 
protected species. You can read all that in the biosphere reserve report [...]. We have arranged activities to monitor birds, monitor butterflies, amphibians, reptiles, and have prepared a list of rare species. This was achieved in collaboration with different research institutions in Serbia." (Interview no. 8)

"I saw literature stating that there is no permanent bear population on Golija. I was surprised because I know there is. We immediately started monitoring and identified 20-25 bears in the first year [...]. Now we have started marking individual members of the population by fitting chip implants and special necklaces." (Interview no. 9)

Monitoring results show that every year a few species previously unrecorded in GSBR are identified. Although this might be interpreted as an increase in biodiversity, the interviewees stated that the appearance of new species indicates, rather, the incompleteness of previous studies of Golija's flora and fauna.

"Biodiversity is generally very tricky to assess because that would mean decades of research at the same sites and with the same methodology. Whenever we hire a research institution, we are told that a few species have been recorded for the first time. But the truth is that Golija is unexplored [...]. So, we can say that we have come up with new data rather than improved biodiversity." (Interview no. 8)

\section{Challenges of change}

Even though the interviews indicated a range of positive changes brought by BR status, significant ambiguities remain in balancing economic growth and protection (for example, the illegal construction of weekend cottages for tourism purposes). This is also the reason why positive changes are taking place slowly, rather than reaching their full potential, even 20 years after the BR was established.

Some of the challenges can be traced back to the absence of formal legislation dealing with the definition of the BR, which impacts its visibility and reduces responsibility for implementing some activities and documents. Thus, actions in support of establishing a Council and Forum, or formalizing cooperation and the creation of associations at the local level, are left to the good will of the local community and interested stakeholders. Several interviewees spoke about this issue:

"The problem is that the Law on Nature Protection does not mention biosphere reserves at all. We do not have any legal basis for dealing with issues in reserves. The Spatial Plans of the Republic of Serbia in 1996 and 2010 define 10 areas that should obtain the status of biosphere reserve. It's all nice, but the act of declaring a biosphere reserve is simply not sufficient." (Interview no. 8)

"Everything comes down to the good will of the actors [...]. A Council was formed, and I am a member of that Council, but somehow it all goes slowly [...]. Since the creation of the biosphere reserve, there have been two meetings [...]. The Forum involves local communities from Kraljevo, Ivanjica, Novi Pazar, Sjenica and Raskea - but members of the Forum from those 1ocal communities have not been appointed." (Interview no. 17)
"It is well known that in planning we have a problem with scarce input data, and this is highlighted especially when a territory does not coincide with the administrative boundaries of local governments. It is statistically difficult to measure socio-economic indicators [population composition, income, population movement, number of household members] in parts of the municipalities which the Golija-Studenica Biosphere Reserve comprises." (Interview no. 3)

"There are no regulations on way marking in our law. I was in Slovenia; if someone violates the law and removes the trail signs, there is a penalty. We have no punitive measures." (Interview no. 2)

Despite the BR's protected status, some excessive development activities still find their way there. Until recently, the $\mathrm{BR}$ resisted intensive development, such as the creation of ski resorts, but the BR and NP do have a few ski resorts that have negatively impacted the natural environment. The example of Odvraćenica ski resort (located on the outer border of the BR, in the NP) has shown that the development of ski slopes in an entirely new location, outside existing settlements, accelerates the spontaneous and uncontrolled illegal construction of tourist facilities, including in the core zone. Golijska Reka ski slopes were also developed at a previously uninhabited location, this time in the BR itself. Accommodation and recreation infrastructure were built next to the ski slopes. Part of the forest was clear-cut for the ski slope on the very edge of the core zone. Second-hand cable cars were brought to the location, but they fell into disrepair before they were put into operation. The location has never fully conformed to its designated use (Figure 3). The focus of these projects, as well as the current project of the Ski Resorts of Serbia Public Company to build another ski slope at another new location, does not reflect the opinions of the local communities or MO. Due to this, the BR status of Golija was questioned by the UNESCO representative who visited GSBR after the first periodic report was submitted. One of the interviewees commented:

'Let's be clear, I have nothing against the development of a ski resort and slopes. Golija had a trail and a ski lift 40 years ago [Golijska Reka]. This space should be revitalized, new ski slopes set up, the cable car restored [...]. Many houses in Dajici village are suitable to welcome many of the ski resort's tourists - we need to use these available resources and think of biodiversity - animal species also have their zones and spaces... We don't need to develop an entirely new ski resort that will disturb the habitats of these wild animals in order to make St. Moritz on Golija! The Institute for Nature Conservation of Serbia will certainly agree with what I am saying now." (Interview no. 13)

On the other hand, local self-governments recognize the economic interest of establishing another ski resort in the BR:

"Golija is of national importance and should be supported by the state $[. .$.$] . Local councils have neither the resources nor$ 


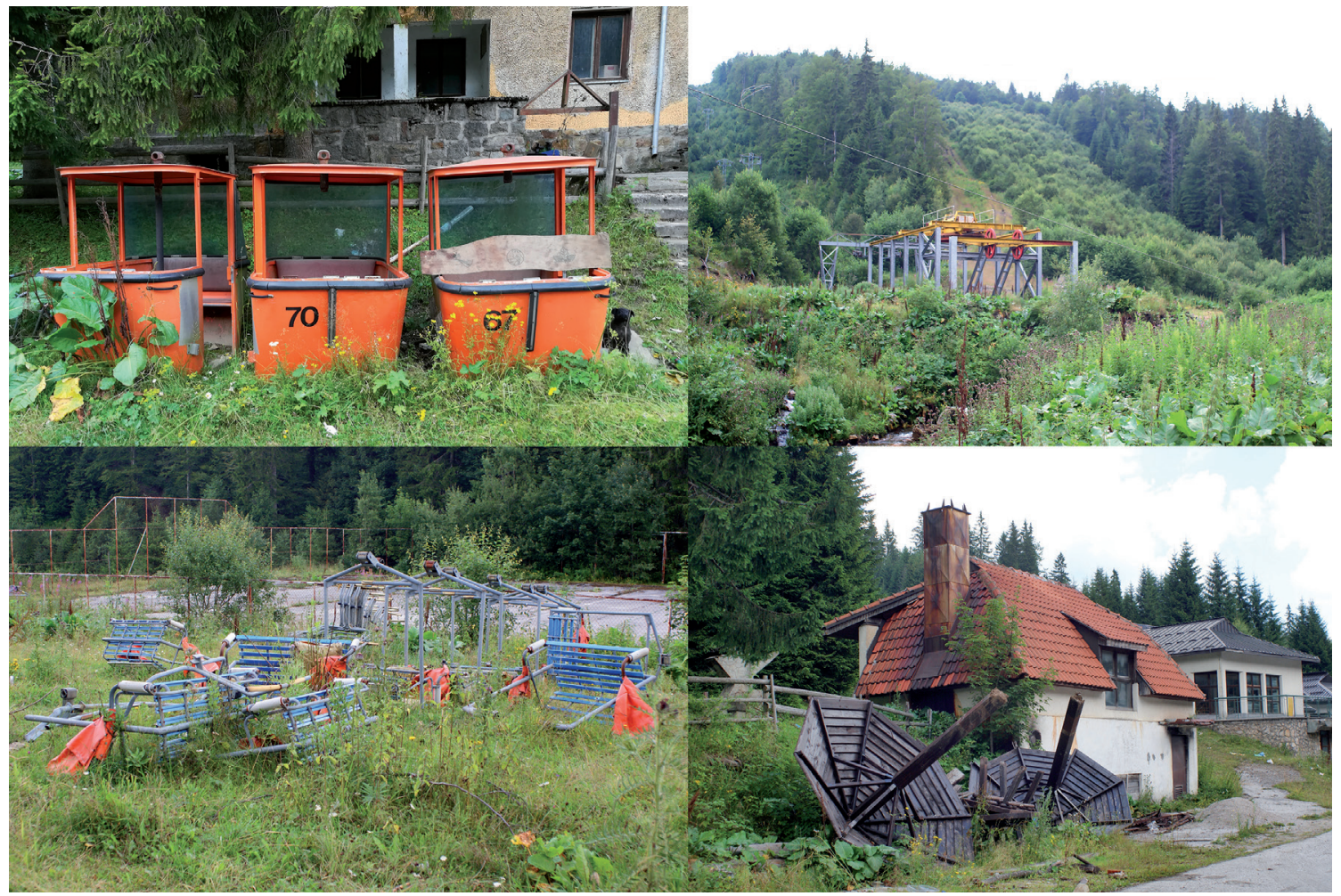

Figure 3 - Golijska Reka ski resort-abandoned before it conformed to its designated use. (C) the authors

the capacity for development activities [...] but they recognize the economic interest of ski resorts because such projects enhance infrastructure development as well. The state financed the Odvracenica-Ivanjica road, which provides us with access to the part of the municipality that was inaccessible before." (Interview no. 18)

Still, most of the other interviewees were sceptical about the development of a new ski resort and emphasized the potentially unfavourable impact on the BR's sustainable development, with only a few positive outcomes for the local population.

"No one is against ski resorts, but a lot of forests will have to be cut down for that purpose." (Interview no. 20)

"Some economic interests can harm the environment [...]. And we already have an old location for a ski resort [Golijska Reka], so why do we need a new one?" (Interview no. 6)

Mini hydropower plants (MHPPs) are an additional environmental issue in GSBR which, combined with the ski resort issue, highlights the difficulties in resolving conflicts between economic growth and environmental protection.

"In fact, mini bydropower plants are the biggest sin [...]. Every mini hydropower plant causes damage to both flora and fauna, and creates a problem for citizens in the maintenance and use of roads because the mini bydropower plant pipes are buried either in riverbeds or under roads. The local population does not benefit from them. In other countries, mini hydropower plants are approved only when there is no other option for power supply in rural areas. ${ }^{1}$ Besides, investors in mini hydropower plants on Golija are rich people usually coming from Belgrade, [and] the local population was deceived. They were told that mini hydropower plants would employ many members of the community [...]. Ultimately, all this [operation of MHPPs] is done by a camera and two people per power plant, but no more." (Interview no. 4)

The general ability to balance development and protection appears to be challenged by an insufficient flow of information, and a lack of knowledge and awareness within the local community. Part of the local population engaged in the exploitation of natural resources sees the $\mathrm{BR}$ as a constraint to their local businesses:

"There are areas of Golija where the benefits of the biosphere reserve are noticeable. We have the example of the village of Rudno as one of the first villages in Serbia to engage in rural tourism. On the other hand, the biosphere reserve status is a problem for some households that are traditionally involved in logging, or extracting stone." 2 (Interview no. 13)

"Some inhabitants think that the protection status should be removed [because it restricts some of their local business activities]. But it's not people's fault. They live in poor conditions and also lack awareness about the economic potential of GolijaStudenica Biosphere Reserve for them." (Interview no. 18)

\footnotetext{
Electricity produced in Golija's MHPPs is distributed externally and not locally.

2 Logging now requires a permit from the Ministry in charge of BRs. The GSBR area is known for its medieval quarries and white Studenica marble; extraction is under strict control.
} 
Regarding the failure to recognize GSBR's new economic potentials, one of the interviewees explains that:

"In Serbia, generally we are not very open to creating associations, cooperatives... Maybe it's because of the unencouraging environment or... Everyone is [socially] cordial to each other, but when it comes to [economic] association, they immediately show resistance. Is it an absence of desire or a simple misunderstanding...?” (Interview no. 6)

Another challenge is related to the lack of staff on local councils or in the Golija NP management office. These institutions rarely assign any employee to deal exclusively with GSBR-related project preparation and implementation.

"The worst thing is that he is alone - the biosphere reserve manager is the only person, there is no one else in that work unit." (Interview no. 4)

"It [successful management] is also a matter of the availability of people, employees in municipalities and cities. It takes a lot of energy and enthusiasm and strength, money and everything to build momentum so that it can go further." (Interview no. 17)

Plans prepared by local municipalities and the NP's management are being implemented only in part. This has a negative impact on stakeholders' willingness to get involved in future participatory processes. One interviewee stated:

"My experience is that there have always been activities and plans for Golija. I've been involved on many occasions. The time has come to see some results! In multiple promotions, discussions and agreements about the aforementioned plans, the outcome is always the same. So, I dare to be a little rude and ask decisionmakers "What have YOU done on Golija in the last 15-20 years, apart from elaborating a couple of projects that haven't been implemented?"' (Interview no. 2, emphasis added)

\section{Discussion}

In order to understand more deeply some of the changes which have occurred in the GSBR, this section outlines the research findings of the BR and examines them in light of the existing literature in the field. The interviews in this research have shown that changing land ownership by selling it to non-local people is viewed in a positive light. From the interviewees' point of view, non-local owners of weekend cottages who have started investing in tourism contribute to the vitality of this depopulated area. Bearing in mind local people's standard of living and awareness of GSBR's potentials, it is likely that it will be the non-local population, rather than the local population, who will be future investors in tourism on Golija (Lakićević \& Sagić 2019). Although Golija's settlements are benefiting from the increasing number of non-local inhabitants (e.g. through public services being maintained), potential negative consequences should be kept in mind before a point of no return is reached (Soszyński et al. 2017). A fading of authenticity, a weakening of the spirit of the place, customs, local products and traditional economic activities, might occur if the nonlocal population outnumbers the local inhabitants as the only mainstay of indigenous Golija culture (Boulouxi 2016; Pantić et al. 2019). This would bring about a substantial change in communities and activities that comprise one of the basic preconditions for establishing and maintaining BR status (Soszyński et al. 2017).

Sustainable development is one of the MAB programme's principles (UNESCO 2020). It is based on the premise that the economic, social and environmental components of development are equally relevant. However, hiding behind capital investments in GSBR (e.g. in a new ski resort) and logging activities are the economic interests of state companies or of private investors coming from more developed regions of the country (e.g. to construct MHPPs). This contradicts one of the advantages of BR status recognized so far - preventing the construction of urban megaprojects, which would have a dramatic impact on natural resources (Castillo-Eguskitza et al. 2017). The benefits for the local population thus boil down to increasing the value of land and the creation of a few jobs. But there are significant consequences for biodiversity when land goes into the hands of non-local profiteers. The earlier development of ski slopes and tourist resorts has resulted in soil erosion, water, soil and air pollution, light pollution, deforestation, loss and fragmentation of natural habitats, noise, reduction of biodiversity, negative changes in the balance of watercourses and groundwater, and sometimes visitor overload (Rodríguez-Rodríguez \& Bomhard 2011; Curčić et al. 2019). Degradation of the ecosystem undermines the natural and landscape values of the BR, which were its key attractions, and above all a precondition for MAB status (Tomić \& Stojsavljević 2013). In the case of small hydropower plants, the channelling of streams into pipelines negatively impacts the local population's water supply (Ristić et al. 2018) as well as degrading the ecosystem. At the same time, the benefits for both local communities and the state are negligible: it is estimated that hydropower plants can produce a maximum of $2-3 \%$ of Serbia's power needs (Ibid). Additionally, the number of jobs provided is insufficient to be considered crucial for local communities (Đurđević 2019).

Implementation of the ski resort project requires "cutting down about $70 \%$ of the forest in the ski slope area" (interviewee). Forest losses are directly related to soil erosion, climate change, air quality and the water regime (Medarević \& Vasiljević 2006; Ristić et al. 2006). While the project is expected to increase the number of foreign tourists (Sagić et al. 2019), it conflicts with rural tourism, which depends on nature's attractions (Ibid). Since the spatial plan for Golija NP is based on 30-year-old data on climate, snow coverage and soil quality (Tomić \& Stojsavljević 2013) and because Golija does not exceed an elevation of $2000 \mathrm{~m}$, the development of ski tourism has become questionable. 
Nowadays, even Alpine resorts face challenges with snowfall and the added cost of artificial snow (Steiger et al. 2019).

Choosing what actions to take depends on the information available, knowledge and education, which are key for the local population's and other stakeholders' awareness. Due to their geographical remoteness and above-average age, the populations of Serbia's mountainous areas often suffer from insufficient information, resulting in their being less open to adopting new knowledge (Pantić 2019). Although local people are aware of the BR status, obstacles to the area achieving its full potential include ignorance about how the BR status may be used to their advantage, and resistance to imposed development. Therefore, engagement in the field of education is crucial (UNDP 2006; Terzić et al. 2014). Pantić (2019) states that government financial support is extremely important to, and objectively needed by, the local population.

Financial challenges also apply to municipal councils. Some of the interviewees stated that local governments and the MO have problems organizing participatory processes, since they are challenged in terms of financial capacities, manpower and suitable venues for meetings. As the governing model of Serbia is insufficiently decentralized, local government has no power to influence how revenues are allocated, so local budgets are insufficient for development ventures (Aničić et al. 2020). In contrast, UNDP emphasizes that the decentralization of protected area management ensures proper environmental management by "strengthening the democratic process by involving local institutions and communities, ensuring effective transfer of power to the local level, increasing accountability, improving local revenue collection and allowing more effective sharing of knowledge for sustainable natural resource management" (UNDP 2006, p. vi). Decentralization is needed to achieve the effective participation of local actors and capacity building. Education plays a major role in fulfilling both these aims (Ibid).

Cooperation is another precondition for successful development that is gradually improving in GSBR, although it is still hampered. By cooperating and sharing, members of local communities and institutions would improve their knowledge. The examples of GSBR and Golija NP show that participatory processes are an opportunity to share and learn. In Italian mountain areas, the cooperation and association of municipalities are legal requirements (Castelein et al. 2006). In France, Bulgaria and Romania, governing bodies for mountain areas exist by law; they comprise elected representatives and many stakeholders at the local and regional levels (Ibid). According to some interviewees, legislative interventions are necessary to encourage cooperation in Serbia, including in GSBR. Given that the law would improve cooperation conditions, the rights of future associates would be less open to abuse and investments would be safer from being misappropriated. This would gradually build trust with regard to cooperation and creating associations.
The BR's role and responsibilities regarding cooperation or the establishment of a Council and Forum is unclear as the BR has no legal status, and its internationally obtained status is ignored in national legislation. The MO is not in a position to ask for funding, establish a Council and Forum, or stop the development of ski resorts, MHPPs or illegal construction. The only financing the MO can obtain is through the status of the NP, but the cost of activities in the BR itself remains uncovered, which runs counter to BR principles (Price et al. 2010; Pool-Stanvliet et al. 2018). Medarević \& Vasiljević (2006) also stress the need to amend the legislation so that it clearly states which activities are allowed in protected nature areas, and can resolve conflicts of interest.

\section{Conclusions}

GSBR was the first BR in Serbia (established two decades ago), and is the only mountainous one. As Ishwaran (2012) states, MAB areas represent excellent laboratories for learning about sustainable development and research. The aim of this study was therefore to provide a contextual understanding of changes in GSBR and draw lessons for future BR development.

Most of the changes brought about by BR status are positive. Since the MO was assigned the duty of protecting the area and MAB principles, the concept of protection has expanded from a focus on forests and biodiversity to monitoring, research, and evaluating the social and cultural capital of GSBR. BR status also inspired the introduction of a participatory approach, and improved communication and cooperation between stakeholders from different sectors, thus raising awareness of what BR status represents. When the planning documents were adopted, BR status increased land value, which led to the development of tourism. As a new source of income, tourism has encouraged some members of the local communities to remain on Golija, and has attracted non-locals as investors and tourists. Indirectly, this has secured the preservation of public services (e.g. local health centres, post offices) in some villages.

Even though BR status has influenced many areas of life, the extent of the positive change is subtle and is developing only slowly, because negative changes are developing in parallel with the positive ones, and an entire range of challenges exist, some exceeding the power of actors at the local level. The increased attraction of the area led to illegal construction, intensive use of some locations for the development of a ski resort, and the installation of derivative-type mini-hydropower plants. The resulting developments seem to be occurring faster than existing institutional capacities can handle. As in other BR areas world-wide, GSBR's development is challenged by institutional and structural flaws - legislation and a centralized governing model. Legally undefined BR status hinders activities such as the functioning of a Council, the forma- 
tion of a Forum, or being provided with financing. No legislation regulates a framework for cooperation and forming associations, the participation of all relevant stakeholders in all planning phases. Therefore, these activities are conducted on the basis of good will or are omitted due to distrust and a fear of abuse. With their lack of staff, specific knowledge and meeting rooms, local institutions do not have the capacity to focus specifically on the BR. The BR's governance is set up so that its financing and decision-making capacities depend on the state.

The lessons learned in this study indicate that the priorities in improving GBSR should be: 1) legislative amendments, 2) decentralization in governing protected areas, and 3) education. Legislative amendments should, first of all, recognize BR status, and regulate the BR's management model. The law should also determine what are acceptable numbers of weekend cottages and non-local investors compared to local households, and restrict intensive development activities. Furthermore, (controlled) development might be accelerated if legislation enforced and clearly regulated participation in the decision-making process, cooperation and association. Responsibilities should be clearly defined so that there is no doubt about who is responsible for what, and what the punitive measures are in case of failure to act. Decentralized governance could be expected to improve management, cooperation and participation, as well as to address the requirements of space (meeting venue, offices), staff and knowledge. The third pillar - education - is of vital importance for empowering staff, the local population and other stakeholders with regard to management, participation, strategic thinking, and for raising awareness about the obligations, rights and opportunities that come with BR status.

\section{Acknowledgments}

The authors gratefully acknowledge the following interviewees for their generosity and willingness to invest time and share knowledge: Glavinić Nenad, Grujičić Katarina, Jančić Gordana, Krsteski Biljana, the Koturović family, Lukić Slavko, Marković Aleksandar, Mijajlović Marica, Miletić Dejan, Novković Zoran, Radoičić Olivera, Roganović Dragan, Šekler Dragoljub, Trkulja Siniša and Vranić Rade.

\section{References}

Adamiak, C. 2016. Cottage sprawl: Spatial development of second homes in Bory Tucholskie, Poland. Landscape and Urban Planning 147: 96-106.

Aničić, J., D. Aničić, A.M. Jelić \& J. Gligorijević 2020. The influence of the local government on Serbia's economic development and its debt reduction. Trendovi u poslovanju VIII 15(1): 55-65.

Berkes, F. 2007. Community-based conservation in a globalized world. PNAS 104(39): 15188-15193.
Boulouxi, A. 2016. Placing a place: Towards a place-conscious education. Sustainable Mediterranean Special Issue 73: 70-73.

Bridgewater, P.B. 2002. Biosphere reserves: special places for people and nature. Environmental Science \&o Policy 5: 9-12.

Bryman, A. 2016. Social Research Methods, $5^{\text {th }}$ edition. Oxford.

Castelein, A., T.T.V. Dinh, M.A. Mekouar \& A. Villeneuve 2006. Mountains and the law: Emerging trends, FAO Legislative Study 75, Rev.1. Rome: Food and Agriculture Organization of the United Nations.

Castillo-Eguskitza, N., A.J. Rescia \& M. Onaindia 2017. Urdaibai Biosphere Reserve (Biscay, Spain): Conservation against development? Science of the Total Environment 592: 124-133.

Chapin, T., G. Kofinas \& C. Folke 2009. Principles of ecosystem stewardship: Resilience-based natural resource management in a changing world. New York.

Čolić, N. \& O. Dželebdžić 2018. Beyond formality: A contribution towards revising the participatory planning practice in Serbia. SPATIUM 39: 17-25.

Cuong, V.C., P. Dart \& M. Hockings 2017a. Biosphere reserves: Attributes for success. Journal of Environmental Management 188: 9-17.

Cuong, V.C., P. Dart, N. Dudley \& M. Hockings 2017b. Factors influencing successful implementation of Biosphere Reserves in Vietnam: Challenges, opportunities and lessons learnt. Environmental Science \& Policy 67: 16-26.

Ćurčić, B.N., U. Milinčić, A. Stranjančević \& M. Milinčić 2019. Can winter tourism be truly sustainable in natural protected areas? Journal of the Geographical Institute "Jovan Cvijić" SASA 69(3): 241-252.

Đurđević, M. 2019. Koliko su zaista štetne male hidroelektrane? Radio slobodna Evropa. Available at: www.slobodnaevropa.org/a/koliko-su-zaista-\%C5\%A1 tetne-male-hidroelektr ane-/29736359.html (accessed: 24/12/2020)

Ferrero, A.M. \& I. Astorkiza 2016. Preferences for rural living: Naturbanization versus accessibility. Review of European Studies 8(3): 284-306.

Hernes, I.M. \& J.M. Metzger 2017. Understanding local community's values, worldviews and perceptions in the Galloway and Southern Ayrshire Biosphere Reserve, Scotland. Journal of Environmental Management 186: 12-23.

Hockings, M., S. Stolton, F. Leverington, N. Dudley \& J. Courrau 2006. Evaluating Effectiveness: A Framework for Assessing Management Effectiveness of Protected Areas. 2nd ed. Gland/Switzerland/Cambridge: IUCN/ WCPA/WRI.

Institute for Nature Conservation of Serbia 2020. Nature Park "Golija”. Available at: www.zzps.rs/wp/ pp-golija/?lang=en (accessed: 05/08/20)

Ishwaran, N. 2012. Science in intergovernmental environmental relations: 40 years of UNESCO's Man and the Biosphere (MAB) Programme and its future. Environmental Development 1: 91-101. 
Kratzer, A. 2018. Biosphere reserves as model regions for sustainability transitions? Insights into the peripheral mountain area Grosses Walsertal (Austria). Applied Geography 90: 321-330.

Kušová, D., J. Tešitel, K. Matejka \& M. Bartoš 2008. Biosphere reserves - An attempt to form sustainable landscapes. A case study of three biosphere reserves in the Czech Republic. Landscape and Urban Planning 84: $38-51$.

Lakićević, M. \& Z. Sagić 2019. Accommodation capacities and their utilization in the function of tourism development: case of Ivanjica. Економика 65(3): 77-88.

Landman, T. 2012. Phronesis and narrative analysis. In: Flyvbjerg, B., T. Landman \& S. Sanford (eds.), Real Social Science: Applied Phronesis: 27-47. New York.

Medarević, M. \& N. Vasiljević 2006. Problems of sustainable forest management implementation - The example of the spatial plan for the special purpose reserve Golija / Serbia. In: Schmithüsen, F., P. Herbst, D. Nonic, D. Jovic \& M. Stanisic (eds.), Legal Aspects of European Forest Sustainable Development. 253-266. Zürich.

O'Riordan, T. \& S. Stoll-Kleemann 2002. Deliberative democracy and participatory biodiversity. In: O'Riordan, T. \& S. Stoll-Kleemann (eds.), Biodiversity, Sustainability and Human Communities. Protecting Beyond the Protected: 87-112. Cambridge and New York.

Pantić, M. 2019. Izazovi demografskih promena u planinskim područima Srbije (eng. Challenges of Demographic Changes in Serbia's Mountain Areas). Belgrade: IAUS.

Pantić, M., J. Živanović Miljković \& S. Milijić 2019. Land Use and Building Regulations: The Case of Spatial Plans for Protected Natural Areas (Serbia). Facta Universitatis, Series: Architecture and Civil Engineering 17(2): 173-187.

Pool-Stanvliet, R. \& J.H. Giliomee 2013. A sustainable development model for the wine lands of the Western Cape: A case study of the Cape Winelands Biosphere Reserve. In: Pool-Stanvliet, R. \& M. Clüsener-Godt (eds.), AfriMAB Biosphere Reserves in Sub-Saharan Africa: Showcasing Sustainable Development. 45-72. Pretoria.

Pool-Stanvliet, R., S. Stoll-Kleemann \& J.H. Giliomee 2018. Criteria for selection and evaluation of biosphere reserves in support of the UNESCO MAB Programme in South Africa. Land Use Policy 76: 654663.

Price, F.M., J.H. Park \& M. Bouamrane 2010. Reporting progress on internationally designated sites: The periodic review of biosphere reserves. Environmental Science \& Policy 13: 549-557.

Reed, G.M. \& F. Egunyu 2013. Management effectiveness in UNESCO Biosphere Reserves: Learning from Canadian periodic reviews. Environmental Science and Policy 25: 107-117.

Ristić, R., R. Kadović, I. Malušević \& S. Belanović 2006. Conflicts between forestry and erosion. In: Schmithüsen, F., P. Herbst, D. Nonic, D. Jovic \& M.
Stanisic (eds.), Legal Aspects of European Forest Sustainable Development: 253-266. Zürich.

Ristić, R., I. Malušević, S. Polovina, V. Milčanović \& B. Radić 2018. Male hidroelektrane derivacionog tipa: beznačajna energetska korist i nemerljiva ekološka šteta. Vodoprivreda 0350-0519, 50(294-296): 311-317.

Rodríguez-Rodríguez, D. \& B. Bomhard 2011. Chapter: Towards Effective Conservation in Mountains: Protected Areas and Biosphere Reserves. In: Austrian MAB Committee (ed.), Biosphere Reserves of the World. Excellence in the clouds?: 24-27.

Ruiz-Mallén, I., E. Corbera, D. Calvo-Boyero, V. Reyes-García \& K. Brown 2015. How do biosphere reserves influence local vulnerability and adaptation? Evidence from Latin America. Global Environmental Change 33: 97-108.

Sabovljević, S.M., G. Tomović, M. Niketić, P. Lazarević, M. Lazarević, J. Latinović, N. Latinović, E. Kabaš, Z.S. Djurović, L. Kutnar, M. Skudnik, J. Pantović, I. Stevanoski, S. Vukojičić \& M. Veljić 2020. New records and noteworthy data of plants, algae and fungi in SE Europe and adjacent regions, 1. Botanica SERBICA 44(1): 81-87.

Sagić, Z., M. Lakićević \& D. Durkalić 2019. Analysis of tourist turnover in a rural tourism destination - case study of Ivanjica. Economics of Agriculture 66(3): 835-850.

Schliep, R. \& S. Stoll-Kleemann, S. 2010. Assessing governance of biosphere reserves in Central Europe. Land Use Policy 27: 917-927.

Schultz, L., A. Duit \& C. Folke 2011. Participation, Adaptive Co-management, and Management Performance in the World Network of Biosphere Reserves. World Development 39(4): 662-671.

Schultz, L. \& C. Lundholm 2010. Learning for resilience? Exploring learning opportunities in BRs. Environmental Education Research 16: 645-663.

Schultz, L., S. West, A. Juárez Bourke, L. d'Armengol, P. Torrents, H. Hardardottir, A. Jansson \& A. Mohedano Roldán 2018. Learning to live with social ecological complexity: An interpretive analysis of learning in 11 UNESCO Biosphere Reserves. Global Environmental Change 50: 75-87.

Soszyński, D., A. Tucki, R. Krukowska \& C. Jaruga 2017. Problems of second-home spatial development in protected areas. Polesie national park case study. Folia Turistica 44: 49-62.

Steiger, R., D. Scott, B. Abegg, M. Pons \& C. Aall 2019. A critical review of climate change risk for ski tourism. Current Issues in Tourism 22(11): 1343-1379.

Teixeira, J.P., V.J. Romano, E.P. Chinarro \& P.O. Fernandes 2019. Strategy Map for Protection of the Biosphere Reserve of the Iberian Meseta. $33^{\text {rd }}$ IBIMA Conference, Granada, Spain.

Terzić, A., Z. Bjeljac, A. Jovičić \& I. Penjišević 2014. Cultural Route and Ecomuseum Concepts as a Synergy of Nature, Heritage and Community Oriented Sustainable Development Ecomuseum "Ibar 
Valley" in Serbia. European Journal of Sustainable Development 3(2): 1-16.

Tomić, N. \& R. Stojsavljević 2013. Spatial Planning and Sustainable Tourism - A Case Study of Golija Mountain (Serbia). European Researcher 65(12-2): 29182929.

Trakolis, D. 2001. Local people's perceptions of planning and management issues in Prespes Lakes national park, Greece. Journal of Environmental Management 61: 227-241.

Trkulja, S. 2005. Spoj funkcija zaštite i razvoja u rezervatu biosfere. In: Filipović, D, S. Stanković \& V. Šećerov (eds.), Planska i normativna zaštita prostora $i$ životne sredine: 403-410. Belgrade.

UNDP 2006. Decentralized Governance of Natural Resources. Part 1: Manual and Guidelines for Practitioners. UNDP.

UNESCO 1995. The Statutory Framework of the World Network of Biosphere Reserves. Paris: UNESCO.

UNESCO 2016. Man and the biosphere programme. Available at: www.unesco.org/new/en/naturalsciences/environment/ecologicalsciences/man-andbiosphere-programme/ (accessed: 02/07/2020)

UNESCO 2017. Golija-Studenica. Available at: www. unesco.org/new/en/natural-sciences/environment/ ecological-sciences/biosphere-reserves/europenorth-america/serbia/golija-studenica (accessed: 05/08/2020)

UNESCO 2020. Technical Guidelines for Biosphere Reserves. Available at: https://en.unesco.org/biosphere/ guidelines (accessed: 22/12/2020)

Vukojičić, S., S. Đurović, E. Kabaš, M. Veljić, N. Kuzmanović, J. Pantović, D. Sekulić \& P. Lazarević
2019. Habitat types inventory in the area of Nature Park Golija in 2018. 13 $3^{\text {th }}$ Symposium on the Flora of Southeastern Serbia and Neighboring Regions. Available at: https://biore.bio.bg.ac.rs/handle/123456789/1825 (accessed: 26/12/2020)

Yihe, L, C. Liding, F. Bojie \& L. Shiliang 2003. A framework for evaluating the effectiveness of protected areas: the case of Wolong Biosphere Reserve. Landscape and Urban Planning 63(4): 213-223.

\section{Authors}

Marijana Pantić - corresponding author is a Research Associate at the Institute of Architecture and Urban \& Spatial Planning of Serbia, Belgrade, Serbia. Her main research fields are regional planning, spatial demography and tourism in the context of mountain area development. E-mail: marijana.d.pantic@gmail.com

\section{Nataša Čolić}

is a Research Associate at the Institute of Architecture and Urban \& Spatial Planning of Serbia, Belgrade, Serbia. Her research interests relate to participatory planning, urban governance and qualitative social research.

\section{Saša Milijić}

is a Principal Research Fellow and the head of the Institute of Architecture and Urban \& Spatial Planning of Serbia, Belgrade, Serbia. His main fields of interest are the sustainable development of mountain areas and tourism development. 